\title{
A fish bone causing ileal perforation in the terminal ileum
}

\author{
Balık kılçığının neden olduğu terminal ileum perforasyonu
}

\author{
Ayhan MUTLU, ${ }^{1}$ Ender UYSAL,${ }^{2}$ Levent ULUSOY, ${ }^{1}$ Cihan DURAN, ${ }^{1}$ Derya SELAMOĞLU ${ }^{1}$
}

Foreign body perforation of the gastrointestinal (GI) tract has diverse clinical manifestations, and the correct preoperative diagnosis is seldom made. We report the case of a 69-year-old woman who experienced severe pain in the right iliac fossa. The presumptive diagnosis was acute purulent appendicitis or diverticulitis. Multidetector computed tomography (MDCT) imaging showed the fish bone perforation of the terminal ileum. A high index of suspicion should always be maintained in order for the correct diagnosis to be made.

Key Words: Bowel perforation; fishbone; multidetector computed tomography.

Foreign body (FB) ingestion is a common clinical problem seen in emergency departments. Most ingested FBs pass through the gastrointestinal (GI) tract uneventfully within one week, ${ }^{[1]}$ and GI perforation is rare, occurring in less than $1 \%$ of patients. ${ }^{[2,3]}$ Fish bones are the most commonly ingested objects and the most common cause of FB perforation of the GI tract. FB perforation of the GI tract has diverse clinical manifestations, and the correct preoperative diagnosis is seldom made.

We report the case of fish bone perforation of the distal ileum, resulting in a clinical presentation mimicking acute appendicitis.

\section{CASE REPORT}

A 69-year-old woman, with no previous abdominal complaints, was admitted to our emergency department with acute abdominal pain in the lower right quadrant for the preceding two days. There was no nausea, vomiting or diarrhea. Physical examination
Gastrointestinal sistemin yabanc1 cisimlerle perforasyonu farklı klinik tablolarla kendini gösterebilir ve operasyon öncesi doğru tanı nadiren konulur. Biz hastanemize sağ alt karın ağrısı ile başvuran, klinik olarak akut apandisit ve divertikülit öntanıları düşünülen, 69 yaşındaki kadın hastanın multidedektör bilgisayarlı tomografi incelemesinde balık kılçığına bağlı terminal ileum perforasyonu saptadık. Bu gibi olgularda doğru tanı koyabilmek için öncelikle klinik olarak şüphelenmek gerekir.

Anahtar Sözcükler: Bağırsak perforasyonu; balık kılçığı; multidedektör bilgisayarlı tomografi. revealed a body temperature of $38.2^{\circ} \mathrm{C}$. An abdominal examination showed localized tenderness in the lower right quadrant with rebound and voluntary guarding. Laboratory tests indicated an elevated white cell count of 12,400 with $88 \%$ neutrophils. A plain X-ray of the abdomen showed local ileus in the lower right quadrant. Sonography of the whole abdomen revealed minimal fluid collection in the pelvic region. The appendix could not be visualized due to the overlying small intestinal loops. The presumptive diagnosis was acute purulent appendicitis and an emergency appendectomy was planned. Before the emergency operation, abdominal multidetector computed tomography (MDCT) imaging was planned for the patient. MDCT showed a localized pneumoperitoneum surrounded by inflammatory mesenteric fat that was found in the vicinity of a short focally thickened ileal segment impacted by the fish bone (Figs. 1, 2). The appendix appeared normal and there was a minimal pelvic fluid collection. The patient was unaware of having ingested a FB, and only the retrospective alimentary inquiry

\footnotetext{
${ }^{1}$ Department of Radiology, Sisli Florence Nightingale Hospital, Istanbul;

${ }^{2}$ Department of Radiology, Sisli Etfal Training and Research Hospital, Istanbul, Turkey.
}

${ }^{1}$ Şişli Florence Nightingale Hastanesi, Radyoloji Bölümü, İstanbul; ${ }^{2}$ Şişli Etfal Eğitim ve Araştırma Hastanesi, Radyoloji Bölümü, İstanbul. 


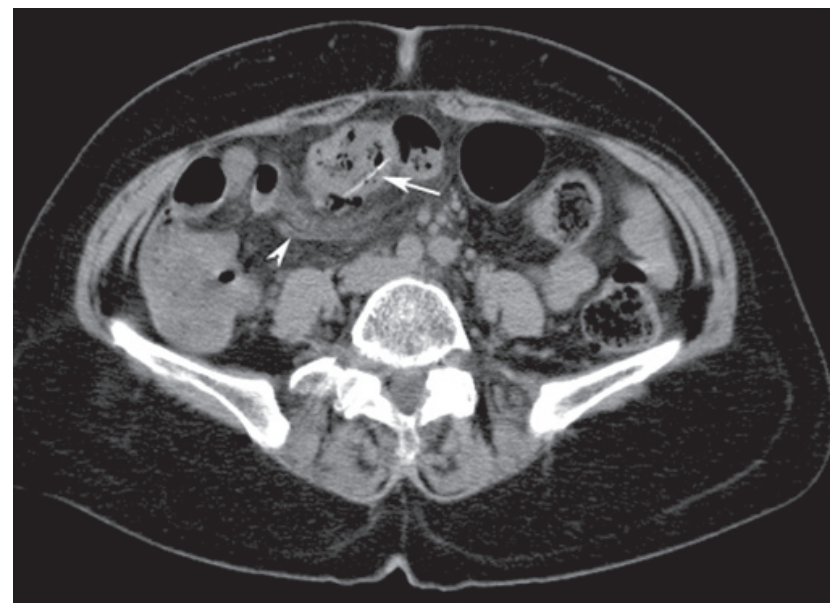

Fig. 1. A localized inflammatory mesenteric fat (arrowhead) is found in the vicinity of a short focally thickened ileal segment impacted by a fish bone (arrow).

revealed the consumption of fish two days before the perforation.

\section{DISCUSSION}

Perforation of the GI tract by ingested FBs is uncommon, and less than $1 \%$ of ingested FBs perforate the bowel. ${ }^{[4,5]}$ Those that cause perforation are usually either sharp, pointed or elongated. ${ }^{[4]}$ They are usually fish bones, toothpicks and chicken bones. FB perforation occurs in all segments of the GI tract, although it tends to occur in regions of acute angulation, such as the ileocecal and rectosigmoid junctions. ${ }^{[2,6]}$ FBs may also perforate through a hernia sac, Meckel's diverticulum, or the appendix. ${ }^{[7]} \mathrm{FB}$ perforation of the GI tract has a wide spectrum of clinical presentations, which can be acute or chronic. Patients occasionally present with unusual or even bizarre clinical manifestations, including hemorrhage, bowel obstruction, and even ureteric colic. ${ }^{[2,7]}$ With these varied and nonspecific

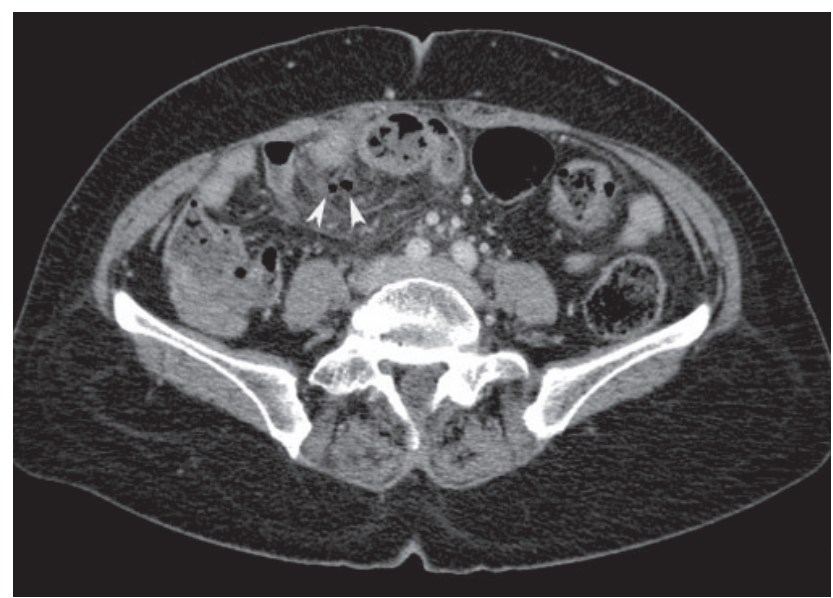

Fig. 2. A localized pneumoperitoneum (arrowhead) surrounded by inflammatory mesenteric fat (white arrow) is also found in the vicinity of the ileal segment. clinical presentations, it is not surprising that FB perforation is seldom diagnosed preoperatively. ${ }^{[8]}$

Voluntary ingestion of one or more FBs is relatively rare and is most common among prisoners and in people who attempt suicide. ${ }^{[6]}$ In most cases of FB ingestion, the patients are unaware and/or the ingestion is accidental, and such ingestions are more common in the extremes of life (children and the elderly, ${ }^{[6]}$ among those with mental disorders and in professionally exposed people (carpenters, dressmakers and upholsterers). Predisposing factors include psychiatric disorders, anti-inflammatory treatments, alcohol or drug abuse, ingestion of extremely cold liquids, poor vision, and rapid eating ${ }^{[6,9,10]}$ the population most susceptible to FB ingestion is people who wear dentures, because the tactile sensitivity of the soft palate that is vital for the detection and recognition of small intra-oral objects is diminished by the presence of dentures. ${ }^{[4]}$

Non-metallic FBs, especially fish bones and other bone fragments, pose a unique problem in the diagnosis of FB perforation. The number of occasions on which these objects are swallowed are numerous and underreported ${ }^{[7]}$ Accidental ingestion of nondietary FBs is a more dramatic event and impresses itself vividly on the patient's memory. ${ }^{[7]}$ The inability to obtain a history of FB ingestion and its wide spectrum of nonspecific clinical presentations make diagnosis of dietary FB perforation extremely difficult.

Radiography is unreliable in the diagnosis of fish bone perforation..$^{[11,12]}$ This problem has been illustrated in studies of fish bone ingestion showing that the degree of radiopacity of the bone depends on the species of fish. ${ }^{[13,14]}$ In contrast, chicken bones are almost always radiopaque. Even when fish bones are sufficiently radiopaque to be visualized on radiographs, large soft-tissue masses and fluid can obscure the minimal calcium content of the bone, particularly in altered or obese patients. ${ }^{[9,11]}$ Another reason for not identifying fish bones on radiographs is use of the peak kilovoltage setting. Subtle calcifications are more easily identified on low-kilovoltage $(70 \mathrm{kV})$ supine films. In contrast, use of $90 \mathrm{kV}$ makes it more difficult to see the offending FB. Results of a prospective study with 358 patients who had swallowed fish bones revealed that radiography had a sensitivity of only $32 \% .{ }^{[15]}$ Another difficulty is that the presence of free gas under the diaphragm is almost never seen in FB perforation of the GI tract. ${ }^{[6]}$ Because the perforation is caused by impaction and progressive erosion of the FB through the intestinal wall, the site of perforation becomes covered by fibrin, omentum or adjacent loops of bowel. This limits the passage of large amounts of intraluminal air into the peritoneal cavity. ${ }^{[6]}$

The potential role of $\mathrm{CT}$ scanning for detecting 
non-metallic FB perforation has been demonstrated by two case series. ${ }^{[11,16]}$ Coulier et al. ${ }^{[11]}$ reported the use of $\mathrm{CT}$ for diagnosing seven patients with non-metallic FB perforation, including three patients with fish bone perforations. The region of perforation can be identified on CT scans as a thickened intestinal segment, localized pneumoperitoneum, regional fatty infiltration, or associated intestinal obstruction. However, none of these findings is specific, and the definitive diagnosis is made by identification of the calcified FB. ${ }^{[11]}$ Fish bone perforation typically appears on CT scans as a linear calcified lesion surrounded by an area of inflammation, as shown in our case.

Despite its superiority over radiography in the diagnosis of fish bone perforation, CT has potential limitations in the detection of intraabdominal fish bones. Goh et al. ${ }^{[16]}$ reported the sensitivity of CT in the detection of intraabdominal fish bones as $71.4 \%(5 / 7)$ for initial reports but this improved to $100 \%(7 / 7)$ on retrospective review of CT scans. The main limitation of CT in the detection of FBs in that study was lack of observer awareness. Their study showed that without a high index of suspicion, an FB can be missed or mistaken for another structure, such as a blood vessel. ${ }^{[11]}$ Another potential limitation of CT is scanning thickness. Use of thinner CT slices allows reviewers to better trace structures such as blood vessels and differentiate them from calcified FBs. Coulier et al. ${ }^{[1]}$ emphasized the importance of the thickness of CT slices in the detection of FBs. In their series, FBs were identified preoperatively with $\mathrm{CT}$ in all seven patients. In that study, single-detector helical CT with 3-mm or $1.5-\mathrm{mm}$ slices and MDCT with $1.25-\mathrm{mm}$ or $0.65-\mathrm{mm}$ slices were used, and the images were examined with multiplanar reconstructions and cine mode on workstations. In our case, we used $1.25-\mathrm{mm}$ slices, and images were evaluated on a workstation as our clinical routine. It is not practical for most institutions to use such fine-cut CT scans with $3 \mathrm{D}$ reconstruction to examine all patients presenting with an acute abdomen. Nonetheless, it would not be unreasonable for institutions with single-detector equipment to rescan the abscess region in thinner sections to identify a subtle FB. The orientation of an FB with respect to an axial $\mathrm{CT}$ scan also can affect the perception of the viewer. Coronal reconstruction would be especially useful in overcoming this limitation.

The use of oral and intravenous (IV) contrast material during $\mathrm{CT}$ can cause difficulty in identifying fish bones. Goh et al. ${ }^{[16]}$ reported that oral contrast media can obscure fish bones in the intestinal lumen, causing them to be missed. This problem can be ameliorated with the use of 16-MDCT, in which only water is used to distend the stomach and bowel loops. They also noted that fish bones appear more attenuated and can be appreciated with careful windowing of CT images.

Perforation of intestinal structures by ingested FBs is a challenging diagnosis that should always be kept in mind in cases of acute abdominal symptoms; this case study showed the utility of MDCT in the detection of fish bone perforation of the GI tract.

\section{REFERENCES}

1. McCanse DE, Kurchin A, Hinshaw JR. Gastrointestinal foreign bodies. Am J Surg 1981;142:335-7.

2. Maleki M, Evans WE. Foreign-body perforation of the intestinal tract. Report of 12 cases and review of the literature. Arch Surg 1970;101:475-7.

3. McPherson RC, Karlan M, Williams RD. Foreign body perforation of the intestinal tract. Am J Surg 1957;94:564-6.

4. Noh HM, Chew FS. Small-bowel perforation by a foreign body. AJR Am J Roentgenol 1998;171:1002.

5. Rasheed AA, Deshpande V, Slanetz PJ. Colonic perforation by ingested chicken bone. AJR Am J Roentgenol 2001;176:152.

6. Pinero Madrona A, Fernández Hernández JA, Carrasco Prats M, Riquelme Riquelme J, Parrila Paricio P. Intestinal perforation by foreign bodies. Eur J Surg 2000;166:307-9.

7. Ginzburg L, Beller AJ. The clinical manifestations of nonmetallic perforating intestinal foreign bodies. Ann Surg 1927;86:928-39.

8. Ashby BS, Hunter-Craig ID. Foreign-body perforations of the gut. Br J Surg 1967;54:382-4.

9. Maglinte DD, Taylor SD, Ng AC. Gastrointestinal perforation by chicken bones. Radiology 1979;130:597-9.

10. Coulier B. Diagnostic ultrasonography of perforating foreign bodies of the digestive tract. [Article in French] J Belge Radiol 1997;80:1-5.

11. Coulier B, Tancredi MH, Ramboux A. Spiral CT and multidetector-row CT diagnosis of perforation of the small intestine caused by ingested foreign bodies. Eur Radiol 2004;14:191825.

12. Goh BK, Jeyaraj PR, Chan HS, Ong HS, Agasthian T, Chang $\mathrm{KT}$, et al. A case of fish bone perforation of the stomach mimicking a locally advanced pancreatic carcinoma. Dig Dis Sci 2004;49:1935-7.

13. Kumar M, Joseph G, Kumar S, Clayton M. Fish bone as a foreign body. J Laryngol Otol 1998;112:360-4.

14. Ell SR, Sprigg A. The radio-opacity of fishbones--species variation. Clin Radiol 1991;44:104-7.

15. Ngan JH, Fok PJ, Lai EC, Branicki FJ, Wong J. A prospective study on fish bone ingestion. Experience of 358 patients. Ann Surg 1990;211:459-62.

16. Goh BK, Tan YM, Lin SE, Chow PK, Cheah FK, Ooi LL, et al. CT in the preoperative diagnosis of fish bone perforation of the gastrointestinal tract. AJR Am J Roentgenol 2006;187:710-4. 